\title{
Oral health in postmenopausal and premenopausal women after myocardial infarction in Poland: a preliminary study
}

\author{
Bartłomiej Górski, Ewa Ganowicz, Renata Górska \\ Department of Oral Medicine and Periodontal Diseases, Medical University of Warsaw, Warsaw, Poland
}

\begin{abstract}
Introduction: Age and hormonal disorders are recognized factors impacting the periodontium and the prevalence of cardiovascular diseases, but as yet the relationship between these two conditions in postmenopausal (post-M) and premenopausal (pre-M) women in Poland has not been assessed. The aim of this study was to compare the periodontal status in women after myocardial infarction (MI) with women without $\mathrm{MI}$ history and to determine risk factors for periodontitis.

Material and methods: The study included 35 women hospitalized due to Ml, average age $54.7 \pm 9.4$ years, and 96 women randomly drawn from the general population, average age $56.1 \pm 10.0$ years. All women were checked for periodontitis risk factors (education, socioeconomic status, tobacco smoking, stress), and underwent dental examination.

Results: The lowest number of teeth was found in post-M women after MI (median = 8), whereas pre-M women without MI history had 25 teeth. Edentulousness occurred more frequently in post- $M$ women compared with pre-M women ( $12.2 \%$ vs. $0 \%)$, the same was observed for advanced periodontitis ( $28.4 \%$ vs. $21.1 \%)$. The severity of periodontitis was highest in the post-M subgroup (more than half demonstrated advanced periodontitis or edentulousness). The most important risk factor for periodontitis, regardless of age, was the level of education. In post- $M$ women the second risk factor was smoking, while in pre- $M$ women negative stress.

Conclusions: The status of oral health in post-M women is unsatisfactory, particularly in those affected by cardiovascular diseases. It is necessary to take preventive and educational measures targeted at these women.

Key words: menopause, periodontal disease, myocardial infarction, risk factors, education, tobacco smoking, stress.
\end{abstract}

\section{Introduction}

Periodontal diseases are diseases that have multifactorial origin, in most cases associated with bacterial etiology. The occurrence and severity of periodontitis correlates with certain risk factors that can be divided into non-modifiable and modifiable ones. The former include: age, male gender, low education and low socioeconomic status [1]. Cigarette smoking, stress, obesity, and certain systemic diseases (such as diabetes, osteoporosis) constitute modifiable risk factors for periodontal diseases [1-3].

The prevalence of periodontitis increases with age, advanced periodontitis occurs in $1 \%$ of people aged 20-29 years, compared to $39 \%$ in individuals older than 65 years [4]. This was confirmed by studies carried out in recent years in Poland, which included randomly selected individuals aged 35-44 and 65-74 years $[5,6]$. Healthy periodontium was observed in $1.62 \%$ of patients aged $35-44$ and in $0.75 \%$ of those aged 65 74 years. The most advanced disease was observed in $19.47 \%$ of patients aged $35-44$ years and in $31.89 \%$ of patients 65-74 years old. The condition of periodontal tissues in females was better than in males.

Numerous studies indicate a significantly lower prevalence of periodontal diseases in women, which is explained by their better behavior regarding oral health and by environmental factors $[1,5,6]$. Women demonstrate better oral hygiene, they are less vulnerable to addictions (smoking, alcohol drinking) and visit the dentist more frequently for check-ups. However, women after menopause demonstrated a relationship between resorption of the alveolar bone in maxilla and the alveolar part of the mandible on one hand and osteoporosis on the other hand. Destruction of periodontal tissues was greater in postmenopausal female smokers [7]. These processes are caused by a decrease in estrogen levels due to termination of the ovarian function. The effect of estrogens on osteoblasts is inhibition of cytokine secretion by these cells (IL- $1 \alpha$, IL-1 $\beta$, IL- 6 , TNF- $\alpha$ ), which are paracrine stimulators of maturation and osteoblast activity. Thus, with a reduced concentration of estrogen, resorption activity of osteoclasts rises, 
resulting in increased resorption of periodontal bone structures in postmenopausal women.

The literature on the subject presents a few classifications of periodontal diseases [8-12]. For many years researchers have postulated the existence etiologic relationships between periodontal and cardiovascular diseases, including acute coronary syndromes (ACS) [13-16]. In 2010, cardiovascular diseases were responsible for $46.0 \%$ of all deaths of Poles $(40.8 \%$ of male deaths and $51.8 \%$ of deaths in women) [17]. They caused 174,003 deaths, i.e. 456 per 100 thousand of population (469 women per 100 thousand, and 442 men per 100 thousand). Cardiovascular disorders constitute a much more common cause of death among Polish citizens than the average in other countries and in the European Union [18]. Cardiovascular diseases typically cause more deaths in women than in men, but this is due to the older age structure of women. After eliminating the differences in the two structures, it turns out that these diseases constitute a much greater threat to the lives of men, as the standardized death rate in 2010 for men in Poland was about 69\% higher than for women. Cardiovascular diseases are a dominating cause of death of female Poles above 69 years of age, ceding the first place to cancer in the 30-69 years age group, and to external causes in younger women. Nevertheless, this represents a very big social problem, which is also heavy on the insurance system in Poland.

Epidemiological studies show that patients with periodontitis have a higher risk of coronary heart disease and of acute coronary syndrome [19]. However, the oral health of Poles with cardiovascular diseases is far from satisfactory [20-24]. To date in Poland no epidemiological studies have been carried out, assessing the status of periodontal tissues in women at the menopausal age with acute coronary syndrome. Therefore, the aim of this study was to determine the condition of the periodontal tissues and the number of teeth present in the oral cavity in female patients aged $\geq 55$ years freshly after acute myocardial infarction (MI) and in women without cardiovascular conditions, compared to women aged $<55$ years, using the Community Periodontal Index (CPI) and the epidemiological classification of periodontitis by Page and Eke. The authors have also attempted to discuss the impact of selected risk factors on periodontal tissue status in women at menopausal and post-menopausal age, compared to younger women.

\section{Material and methods}

The study included 35 female patients hospitalized in the $1^{\text {st }}$ Department and Clinic of Cardiology, Medical University of Warsaw due to fresh MI. The inclusion criteria were $\mathrm{MI}$ history and age below 70 years. The exclusion criteria were medical history with ongoing neoplastic disease, rheumatic disease, autoimmune disease, chronic liver disease, chronic renal disease stages 4 and 5 , and prior stroke.

The control group consisted of 96 women aged 40 to 69 years with no MI history, drawn by the Ministry of Interior and Administration, who reported to the Department of Oral Medicine and Periodontal Diseases, Medical University of Warsaw.

The study was carried out in accordance with the Helsinki Declaration of 1975, as revised in 2000 (concerning the ethical principles for the medical community and forbidding releasing the name of the patient, initials or the hospital records number) and with the ethical standards of the responsible committee on human experimentation (institutional and national). All individuals participating in the study gave their consent by signing a declaration approved by the Bioethics Commission at the Medical University of Warsaw (Opinion No. KB-145/2011).

The study was conducted from 2010 to 2013. The limit for pre- and postmenopausal age was assumed at 55 years. The study group included 35 patients. The average age of this group was $54.7 \pm 9.4$ years, including 20 women aged $\geq 55$ years and 15 women aged $<55$ years. The control group included 96 individuals. The average age of this group was $56.1 \pm 10.0$ years, 54 women were aged $\geq 55$ years, and 42 were aged $<55$ years.

A dental examination was performed in artificial light, with the use of a dental mirror and periodontal probe (Hu-Friedy PCPUNC 15) calibrated every millimeter. The pressure force of the probe during measurement did not exceed $0.25 \mathrm{~N}$ (25 g). The examination did not include third molars. The clinical examination involved:

- bleeding on probing index (BoP) by Ainamo and Bay [21]; the examination was conducted at four points around the tooth: mesiobuccal - MB, buccal - B, distobuccal - DB, and lingual - L; only the presence or absence of gingival bleeding during pocket probing was determined, and the BoP value was expressed as a percentage of bleeding sites;

- pocket depth (PD) at 4 points around the tooth: MB, $B, D B, L$, which is defined as the distance from the gingival margin to the bottom of the pocket identified by probing;

- clinical attachment level (CAL) at 4 points around the tooth: MB, B, DB, L; which is defined as the distance between the bottom of the pocket identified by probing and the cementoenamel junction.

The periodontal status of each patient was categorized according to the $\mathrm{CPI}$ codes:

- CPI-0 - no symptoms of inflammation,

- $\mathrm{CPI}-1$ - presence of bleeding on probing,

- CPI-2 - presence of supra- and/or subgingival calculus, or overhangs,

- CPI-3 - presence of periodontal pockets from 3.5 to $5.5 \mathrm{~mm}$ deep, 


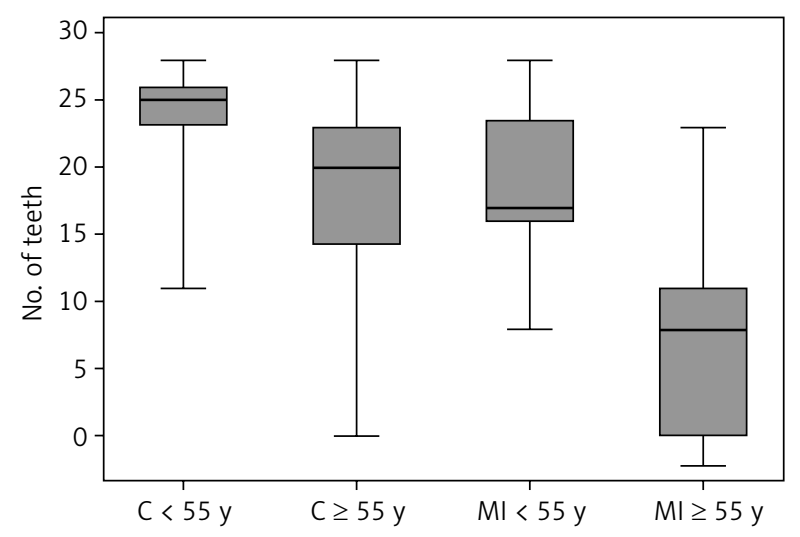

$\mathrm{C}$ - control group, $\mathrm{Ml}$ - women after myocardial infarction

Fig. 1. Comparison of median teeth number. Kruskal-Wallis ANOVA test, $p=0.0001$

- CPI-4 - presence of periodontal pockets at least $5.5 \mathrm{~mm}$ deep.

The diagnosis was also categorized on the basis of the definition of periodontitis by Page and Eke:

- mild periodontitis - 2 or more teeth with $C A L \geq 3 \mathrm{~mm}$ on proximal surfaces and 2 or more teeth with PD $\geq 4 \mathrm{~mm}$ on proximal surfaces;

- moderate periodontitis - 2 or more teeth with CAL $\geq 4 \mathrm{~mm}$ on proximal surfaces, or two or more teeth with $\mathrm{PD} \geq 5 \mathrm{~mm}$ on proximal surfaces;

- severe periodontitis - 2 or more teeth with CAL $\geq 6 \mathrm{~mm}$ on proximal surfaces and one or more teeth with $\mathrm{PD} \geq 5 \mathrm{~mm}$ on proximal surfaces;

- other clinical situations were defined as "no periodontitis" or healthy periodontium.

The prevalence of selected risk factors for periodontal diseases was determined using medical history provided by the patient:

- education was defined as primary, secondary and higher education;

- socioeconomic status was defined on the basis of income per family member: < PLN 800, PLN 800-1500, > PLN 1500 per month;

- nicotinism was defined as: current (smoking at least 10 cigarettes per day continuously for a minimum of 5 years), in the past and never;

- the presence of negative stress was defined by patients on a 0-1 scale, where 0 - no stress, 1 - frequent negative stress.
The data obtained from history and clinical examinations were statistically analyzed using the PQStat software, with $\chi^{2}$ test, Kruskal-Wallis ANOVA with posthoc analysis by Dunn, and backward stepwise multiple regression procedure. The threshold for statistical significance was assumed at $p<0.05$ for univariate analyses and $p<0.2$ for multivariate analyses.

\section{Results}

A comparative analysis of the number of remaining teeth (Fig. 1) demonstrated by far the worst situation in the subgroup of postmenopausal women with MI history, whose median number of teeth was only 8 . Relatively the largest number of preserved teeth, equal to 25 , was observed in the group of younger women $(<55$ years) with no history of MI. Postmenopausal women without $\mathrm{MI}$ history and premenopausal women after acute coronary syndrome (ACS) belonged to the two moderate groups (median number of teeth was 20 and 17, respectively). The differences between all groups were statistically significant, except for the comparison of the two subgroups of patients without MI history (Table I).

Table II presents the assessment of periodontal status in the study groups, expressed by the CPI. Compared to younger women, postmenopausal women demonstrated a significantly higher occurrence of edentulousness and advanced periodontitis, as well as healthy periodontium, thus a greater polarity compared to younger women. Comparison of women after an acute coronary episode to those without MI history explicitly indicated a worse periodontal status in women after MI.

When women in the study were divided into four groups, with respect to both age and MI history, the most advanced periodontitis (as expressed by CPI value) was observed in the postmenopausal group with $\mathrm{MI}$ history (Fig. 2) and there was also a difference close to statistical significance between this group and women $\geq 55$ years without prior MI (Table III).

When the classification of periodontal status by Page and Eke was used for comparison, it yielded slightly different results - postmenopausal women demonstrated visibly worse periodontal health compared to the younger ones: increased occurrence of

Tab. I. Post-hoc analysis of median teeth number, according to Dunn

\begin{tabular}{lcccc}
\hline & No $\mathbf{M l}$, age $<55$ years & No $\mathbf{M l}$, age $\geq 55$ years & Ml, age $<55$ years & Ml, age $\geq 55$ years \\
\hline No $\mathrm{Ml}$, age $<55$ years & - & 1.000 & 0.0255 & 0.0125 \\
\hline No $\mathrm{Ml}$, age $\geq 55$ years & 1.000 & - & $<0.0001$ & 0.0007 \\
\hline Ml, age $<55$ years & 0.0255 & $<0.0001$ & - & $<0.0001$ \\
\hline Ml, age $\geq 55$ years & 0.0125 & 0.0007 & $<0001$ & - \\
\hline Ml - myocardial infarction & & & &
\end{tabular}


Tab. II. Community periodontal index (CPI) distribution in subgroups

\begin{tabular}{|c|c|c|c|c|c|c|}
\hline CPI classification & $\mathrm{CPI}=1$ & $\mathrm{CPI}=2$ & $\mathrm{CPI}=3$ & $\mathrm{CPI}=4$ & Edentulous & $\begin{array}{c}\text { Comparison } \\
\left(\chi^{2} \text { test }\right)\end{array}$ \\
\hline Women after MI $(n=35)$ & $2(8.6 \%)$ & $3(8.6 \%)$ & $11(31.4 \%)$ & $13(37.1 \%)$ & $6(17.1 \%)$ & \multirow{2}{*}{$p=0.0063$} \\
\hline Control group $(n=97)$ & $16(16.5 \%)$ & $23(23.7 \%)$ & $32(33.0 \%)$ & $23(23.7 \%)$ & $3(3.1 \%)$ & \\
\hline Women aged $\geq 55$ years $(n=74)$ & $15(20.3 \%)$ & $10(13.5 \%)$ & $19(25.7 \%)$ & $21(28.4 \%)$ & $9(12.2 \%)$ & \multirow{2}{*}{$p=0.0005$} \\
\hline Women aged $<55$ years $(n=57)$ & $2(3.5 \%)$ & $16(28.1 \%)$ & $24(42.1 \%)$ & $15(26.3 \%)$ & $0(0 \%)$ & \\
\hline
\end{tabular}

$\mathrm{Ml}$ - myocardial infarction

edentulousness and advanced periodontitis, with less frequent occurrence of healthy periodontium and mild periodontitis (Table IV). Also in the group with MI history, edentulousness and advanced periodontitis were observed more frequently than in women without MI, but the absence of disease or mild periodontitis were observed in fewer cases.

However, a comparison of the women regarding the periodontal status using the Page and Eke classification, including $\mathrm{MI}$ history and age, revealed that MI history made a bigger difference than age (Fig. 3 and Table V), although a noticeably higher degree of severity of periodontitis was observed in postmenopausal women compared to premenopausal individuals.

The correlation between the presence of specific risk factors and the severity of periodontitis was also assessed in the group of women aged $\geq 55$ years and in those aged < 55 years (Table VI). In the group of postmenopausal women a statistically significant relationship was observed for the level of education $(p=0.0393)$, tobacco smoking $(p=0.0225)$ and the level of income $(p=0.0137)$. In the group of premen-

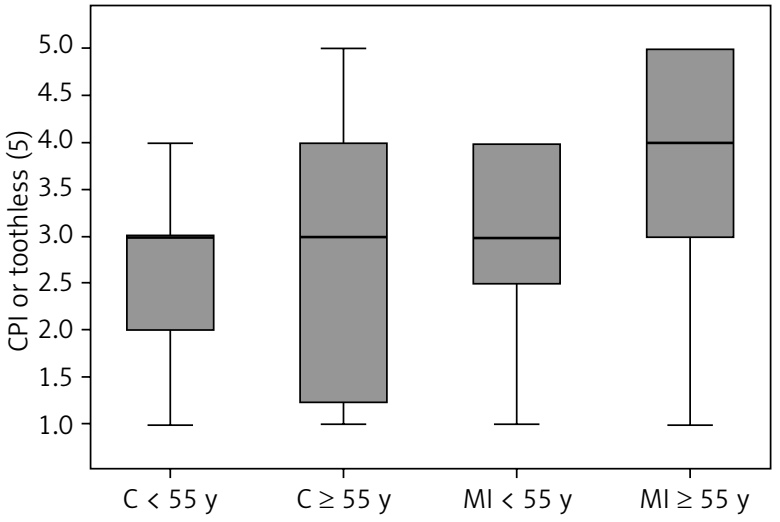

$\mathrm{C}$ - control group, $\mathrm{Ml}$ - women after myocardial infarction

Fig. 2. Comparison of median Community Periodontal Index (CPI) value. Kruskal-Wallis ANOVA test, $p=0.0013$

opausal women, the significant factors correlating with the periodontal status proved to be education $(p<0.0001)$ and income $(p=0.0071)$, and a relationship close to the significance level was observed for stress $(p=0.0686)$.

Tab. III. Post-hoc analysis of median community periodontal index (CPI) value, according to Dunn

\begin{tabular}{|c|c|c|c|c|}
\hline & No $M I$, age < 55 years & No $M I$, age $\geq 55$ years & MI, age $<55$ years & MI, age $\geq 55$ years \\
\hline No MI, age $<55$ years & - & 1.000 & 1.000 & 0.4621 \\
\hline No $M I$, age $\geq 55$ years & 1.000 & - & 0.6781 & 0.0675 \\
\hline MI, age $<55$ years & 1.000 & 0.6781 & - & 1.000 \\
\hline MI, age $\geq 55$ years & 0.4621 & 0.0675 & 1.000 & - \\
\hline
\end{tabular}

$\mathrm{MI}$ - myocardial infarction

Tab. IV. Page and Eke classes distribution in subgroups

\begin{tabular}{|c|c|c|c|c|c|c|}
\hline $\begin{array}{l}\text { Page and Eke } \\
\text { classification }\end{array}$ & $\begin{array}{l}\text { No } \\
\text { periodontitis }\end{array}$ & $\begin{array}{l}\text { Mild } \\
\text { periodontitis }\end{array}$ & $\begin{array}{c}\text { Moderate } \\
\text { periodontitis }\end{array}$ & $\begin{array}{c}\text { Advanced } \\
\text { periodontitis }\end{array}$ & Edentulous & $\begin{array}{c}\text { Comparison } \\
\left(\chi^{2} \text { test }\right)\end{array}$ \\
\hline $\begin{array}{l}\text { Women after } \mathrm{MI} \\
(n=35)\end{array}$ & 4 (11.4\%) & 0 & $12(34.3 \%)$ & $13(37.1 \%)$ & $6(17.1 \%)$ & \multirow{2}{*}{$p=0.0039$} \\
\hline $\begin{array}{l}\text { Control group } \\
(n=97)\end{array}$ & $28(28.9 \%)$ & $4(4.1 \%)$ & $42(43.3 \%)$ & $20(20.6 \%)$ & $3(3.1 \%)$ & \\
\hline $\begin{array}{l}\text { Women aged } \\
\geq 55 \text { years }(n=74)\end{array}$ & $16(21.6 \%)$ & $1(1.4 \%)$ & 27 (36.5\%) & $21(28.4 \%)$ & 9 (12.2\%) & \multirow{2}{*}{$p=0.0334$} \\
\hline $\begin{array}{l}\text { Women aged } \\
<55 \text { years }(n=57)\end{array}$ & $15(26.3 \%)$ & $3(5.3 \%)$ & 27 (47.4\%) & $12(21.1 \%)$ & 0 & \\
\hline
\end{tabular}




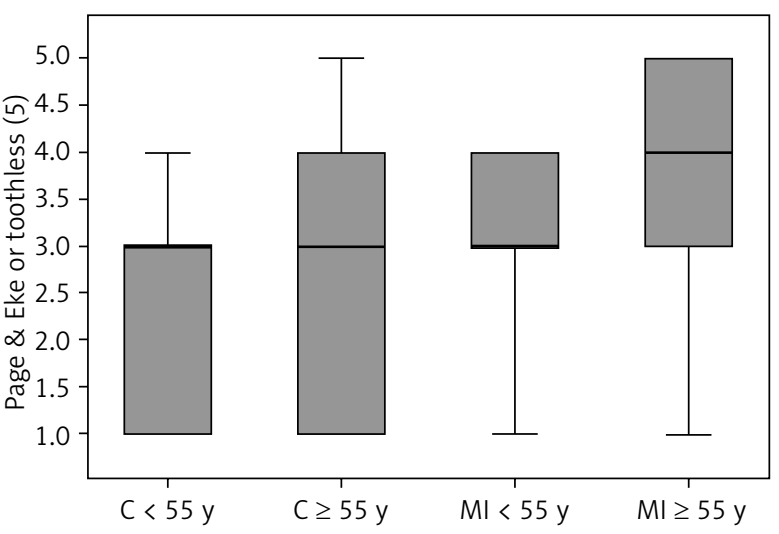

C - control, Ml- myocardial infarction

Fig. 3. Comparison of median Page and Eke class. KruskalWallis ANOVA test, $p=0.0005$
The last stage was a multivariate analysis of potential risk factors for periodontal diseases (Table VII). This analysis was conducted separately for post- and premenopausal women, in order to determine whether these groups demonstrate differences concerning the degree to which various factors impact the occurrence of periodontitis. It was observed that in both groups the most important risk factor was the level of education. The second factor was smoking in the case of women aged $\geq 55$ years, while in women aged $<55$ years - the presence of negative stress.

\section{Discussion}

Studies assessing the condition of periodontal tissues in patients with cardiovascular diseases in Poland have included more men than women, unfortunately

Tab. V. Post-hoc analysis of median Page and Eke class, according to Dunn

\begin{tabular}{lcccc}
\hline & No MI, age $<55$ years & No $\mathbf{M l}$, age $\geq 55$ years & Ml, age $<55$ years & MI, age $\geq 55$ years \\
\hline No Ml, age $<55$ years & - & 0.1108 & 0.2032 & 0.0028 \\
\hline No Ml, age $\geq 55$ years & 0.1108 & - & 1.000 & 0.6302 \\
\hline MI, age $<55$ years & 0.2032 & 1.000 & - & 1.000 \\
\hline MI, age $\geq 55$ years & 0.0028 & 0.6302 & 1.000 & - \\
\hline Ml - myocardial infarction & & & &
\end{tabular}

Tab. VI. Correlation between the periodontal state (expressed as Page \& Eke class) and potential risk factors in women of premenopausal and postmenopausal age

\begin{tabular}{|c|c|c|c|c|}
\hline \multirow[t]{2}{*}{ Factors } & \multicolumn{4}{|c|}{ Periodontal state (median Page \& Eke class) } \\
\hline & $\begin{array}{l}\text { Women aged } \geq 55 \\
(n=74)\end{array}$ & $\begin{array}{c}\text { Comparison } \\
\text { (Kruskal-Wallis ANOVA) }\end{array}$ & $\begin{array}{c}\text { Women aged }<55 \\
(n=57)\end{array}$ & $\begin{array}{c}\text { Comparison } \\
\text { (Kruskal-Wallis ANOVA) }\end{array}$ \\
\hline \multicolumn{5}{|l|}{ Education } \\
\hline Primary & 4 & \multirow{3}{*}{$p=0.0393$} & 4 & \multirow{3}{*}{$p<0.0001$} \\
\hline Secondary & 3 & & 3 & \\
\hline University & 3 & & 3 & \\
\hline \multicolumn{5}{|l|}{ Smoking } \\
\hline Never & 3 & \multirow{3}{*}{$p=0.0225$} & 3 & \multirow{3}{*}{$p=0.3740$} \\
\hline Past smoker & 3 & & 3 & \\
\hline Current smoker & 4 & & 3 & \\
\hline \multicolumn{5}{|l|}{ Stress } \\
\hline Low & 4 & \multirow{2}{*}{$p=0.8537$} & 3 & \multirow{2}{*}{$p=0.0686$} \\
\hline High & 4 & & 3 & \\
\hline \multicolumn{5}{|l|}{ Income } \\
\hline $\operatorname{Low}^{\star}$ & 4 & \multirow{3}{*}{$p=0.0137$} & 4 & \multirow{3}{*}{$p=0.0071$} \\
\hline Medium $^{\star *}$ & 3 & & 3 & \\
\hline $\operatorname{High}^{\star * *}$ & 4 & & 3 & \\
\hline
\end{tabular}


the periodontal status depending on gender has not been compared [20, 23].

Włosowicz et al. [19, 22], using the classification of periodontal diseases by American Academy of Periodontology (AAP), studied 112 patients ( 27 females and 85 males) after MI, and 67 patients ( 24 females and 43 males) with stable angina pectoris aged $53.4( \pm 6.5)$ years, and observed mild periodontitis in $32 \%$ of women, advanced periodontitis in $15 \%$ and edentulousness in $26 \%$ of women. These results were considerably better than in men, where the scores were $65 \%, 85 \%$ and $74 \%$, respectively. Thus, the situation described by these authors differed significantly from the results of our study, where - although lower prevalence of edentulousness in women after $\mathrm{Ml}$ (17.1\%) was observed, and $11.4 \%$ of women did not have periodontitis - advanced periodontitis occurred much more frequently (37.1\%). The status of periodontal tissues was better in women without cardiovascular history, which is reflected by a lower edentulousness rate $-3.1 \%$, and lower occurrence of advanced periodontitis $-20.6 \%$.

Sosińska [24] also examined 160 patients (35 women, 125 men) aged 33-65 years hospitalized due to MI. Seventeen percent $(17.14 \%)$ of women were aged 45 54 years, and $82.96 \%$ were $55-65$ years old. Using the CPI classification, the author confirmed a better status of periodontal tissues of the hospitalized women, where $7.69 \%$ were classified with the CPI-2 code, half of the women with the CPI-3, and slightly fewer $-42.31 \%$ - with the CPI-4 code. The values for men were $0.94 \%$, $36.79 \%, 62.26 \%$, respectively. In our study, the CPI-2 code was observed in $8.6 \%$ of women after $\mathrm{MI}$, the CPI-3 code in $31.4 \%$, the CPI- 4 code in $37.1 \%$ of women, so the results were similar to those reported by the quoted authors.

Similar results were obtained by Sosińska with the use of the definition of periodontitis by Page and Eke. The author recorded $9.85 \%$ of individuals who were healthy or had mild periodontitis $(19.23 \%$ of women and $7.55 \%$ of men). On average, moderate periodontitis was observed in $36.36 \%$ of patients $(46.15 \%$ of women and $33.96 \%$ of men). Severe periodontitis was diagnosed in $53.78 \%$ of patients $(34.62 \%$ of women and $58.49 \%$ of men). As for the status of dentition in the study group, $17.50 \%$ of edentulous individuals were observed. A higher percentage of edentulousness occurred in women (25.71\%) than in men (15.20\%). Among men, the percentage of patients with more than six teeth was higher $(73.60 \%)$ than in women $(28.57 \%)$. The relationships between the number of teeth and gender were statistically significant. Our findings are very similar for women after MI, while the status of periodontal tissues in women in the control group, evaluated with the use of the epidemiological definition by Page and Eke, is definitely better. An assessment of the number of remaining teeth showed a dramatic situation in post-
Tab. VII. Potential risk factors for periodontitis in women aged $\geq 55$ years and $<55$ years. Factors included in multifactorial analysis: fresh myocardial infarction (MI), education, smoking, stress, income

\begin{tabular}{|c|c|c|}
\hline \multicolumn{3}{|c|}{$\begin{array}{l}\text { Model of periodontitis risk factors } \\
\text { (periodontitis classified according to Page and Eke) }\end{array}$} \\
\hline \multicolumn{3}{|c|}{$\begin{array}{c}\text { Women aged } \geq 55 \text { years } \\
\text { Multiple backward stepwise regression. } \\
R^{2}=0.1680 ; p \text { for } \text { model }=0.0064\end{array}$} \\
\hline Independent variable & Standardized $b$ coefficient & $p$ value \\
\hline Education & -0.2787 & 0.0283 \\
\hline Smoking & 0.2715 & 0.0324 \\
\hline \multicolumn{3}{|c|}{$\begin{array}{c}\text { Women aged }<55 \text { years } \\
\text { Multiple backward stepwise regression. } \\
R^{2}=0.3990 ; p \text { for model }<0.0001\end{array}$} \\
\hline Independent variable & Standardized $b$ coefficient & $p$ value \\
\hline Education & -0.5735 & $<0.0001$ \\
\hline Stress & 0.1775 & 0.1682 \\
\hline
\end{tabular}

menopausal women with MI history, where the median for the number of teeth was only 8. By comparison, in premenopausal women with no MI history the median number of remaining teeth was 25 .

Therefore, it should be postulated that the poorer condition of periodontal tissues assessed with both the CPI scale as well as with the epidemiological definition by Page and Eke concerned the women after MI, compared to women without cardiovascular history. Considering the age, poorer results were observed in women older than 55 years, that is in the postmenopausal period. When the studied women were divided into four groups, with regard to both age and MI history, the most advanced periodontitis was observed in the postmenopausal group after MI. The importance of age as a risk factor for periodontal diseases has been confirmed in many studies on large samples in Poland as well as across the world [1, 4-6]. This may be due to the cumulative action of dental plaque and/or aging of the body, which results in reduced immunological resistance and increased susceptibility to infections.

While assessing selected risk factors for periodontal diseases, it was found that education and income levels correlated with the status of periodontium regardless of the age of female patients. Smoking correlated with the index of the periodontal status only in the group of postmenopausal women, while the relationship between the severity of periodontitis and stress affected only younger women.

Due to the existing relationships between individual risk factors, they were subjected to a backward stepwise multiple regression analysis. On the basis of this analysis, it was observed that the level of education was the most significant risk factor, both in postmenopausal women (standardized coefficient 
$b=-0.2787, p=0.0283)$ and in premenopausal women (standardized coefficient $b=-0.5735, p<0.0001$ ). The second factor was smoking in the case of women aged $\geq 55$ years (standardized coefficient $b=0.2715$, $p=0.0324$ ), whereas in women $<55$ years - the level of experienced stress (standardized coefficient $b=0.1775$, $p=0.1682$ ).

It should be noted that the absence of other factors among the parameters demonstrating an independent correlation with periodontal status does not mean that they do not play any role at all. However, it confirms the existence of interrelationships between individual risk factors - such as socioeconomic status, widely considered to be one of the risk factors for periodontitis, can be derived from the level of education. Also other authors reached similar conclusions. In the NHANES 2009-2010 study, $66.9 \%$ of Americans with other than higher education suffered from periodontitis, while in the group with higher education the percentage was $39.3 \%$ [1]. Taking into account the income criterion, periodontitis was observed in $65.4 \%$ of individuals with the lowest income, which contrasts with only $35.4 \%$ of periodontal patients in the group with the best socioeconomic status [1]. Sabbah et al. [25] suggest that the socioeconomic status should not be treated as a whole, because the intensity of social contacts does not correlate with the level of wealth, and each of these factors separately affects the periodontal status.

Absence of tobacco smoking should be interpreted similarly as an independent risk factor in women aged $<55$ years. This is not to question the impact of smoking - its influence on the development of periodontal diseases has been investigated quite thoroughly [3, 7, 26]. Smoking determined by the dose-effect relationship and duration of the addiction negatively affect the status of periodontal tissues and cause a worse response to periodontal treatment $[1,11,22,27]$. This is due to increased production of inflammatory mediators: prostaglandin 2 (PGE2) and interleukin-1 (IL-1), growth of anaerobic bacteria (Tannerella forsythia), increase in the activity of proteolytic enzymes and to multifaceted immune disorders. However, a relationship between smoking and the level of education, the socioeconomic status as well as experienced stress can be expected, which is also confirmed by other studies [28]. In the present study a negative impact of active nicotinism on the periodontal tissue status in postmenopausal women was observed, which can be explained as the result of accumulation during exposure to smoking, the effects of which become visible after 55 years of age. In the NHANES 2009-2010 study in the U.S., periodontitis among current smokers occurred in $64.2 \%$ of patients, and in $39.8 \%$ of non-smokers who had never smoked [1].

The importance of stress in the pathomechanism of periodontal diseases is not fully understood. It seems that mental stress could be conducive to neglecting hygiene, diet changes, more frequent smoking, which may interfere with immunological processes and intensify changes in the defense system [3]. In the current study this parameter was identified in the zero-one system, and the presence of stress correlated with the status of periodontal tissues in women aged under 55 years. Perhaps younger patients turned to smoking as a way of coping with stress, which would explain the significance of this phenomenon in the progression of periodontal diseases in the postmenopausal period.

The results of the study allow identification of the factors on which to focus in potential prevention campaigns aimed at women of all ages. The strongest relationship between the periodontal status and education is also an indication that those campaigns should be targeted mainly at women with primary education or vocational training. The effectiveness of such an approach can only be assessed in the future, when practical steps are undertaken. The problem of nicotine addiction should not be omitted, and postmenopausal women constitute the group which should be targeted with particularly intensive actions.

To the best of the authors' knowledge, this is the first epidemiological study in Poland designed to compare the periodontal status of women in the menopausal and postmenopausal period of life suffering from acute coronary syndrome with healthy subjects. The study results clearly indicate the wide prevalence of periodontitis among Polish women of pre- and postmenopausal age, and the problem is greater in patients after MI. An additional merit of this work is an assessment of the patients' periodontal tissue status using not only the CPI, but also the definition of periodontitis by Page and Eke, which may be useful in comparative analyses in studies of other researchers.

The findings in this study are subject to some limitations. Firstly, the results of periodontal parameter examinations (BoP, PD, CAL) were recorded at four measurement sites, which could affect the underestimation of diagnoses. Secondly, third molars were not assessed due to methodological problems associated with the position of these teeth in the oral cavity. Thirdly, the study group had a small number of women, which was associated with a relatively small number of women hospitalized due to MI (compared to men), who met the age criteria despite the fact that the study was conducted for three years, thus this study deserves to be continued to confirm the obtained results on a larger population of women. Fourthly, the reportability of patients in the control group was $10 \%$, and the majority of patients registered because of ailments specific to periodontopathies, which is reflected in the poor periodontal tissue status in those individuals. It is advisable to carry out research on a larger sample, which would address the above mentioned difficulties. 


\section{Conclusions}

Oral health expressed with the number of remaining teeth, edentulousness index and periodontal diagnosis was decidedly the worst in postmenopausal women with MI history. The most important risk factor for periodontal diseases proved to be the level of education, both in postmenopausal and premenopausal women. The second factor was smoking in the case of women aged $\geq 55$ years and in women aged $<55$ years the level of experienced stress. When planning potential preventive campaigns aimed at women of all ages, the mentioned risk factors should be considered.

\section{Disclosure}

\section{Authors report no conflict of interest.}

\section{References}

1. Thornton-Veans G, Eke P, Wei L, et al. Periodotitis among adults aged $\geq 30$ years - United States, 2009-2010. MMWR 2013; 62: 129-135.

2. Chavarry NG, Vettore MV, Sansone C, Sheiham A. The relationship between diabetes mellitus and destructive periodontal diseases: a metaanalysis. Oral Health Prev 2009; 7: 107-127.

3. Stabholz A, Soskolne A, Shapira L. Genetic and environmental risk factors for chronic periodontitis and aggresive periodontitis. Periodontol 2000 2010; 53: 138-153.

4. Demmer RT, Papapanou PN. Epidemiologic patterns of chronic and aggresive periodontitis. Periodontol 2000 2010; 53: 28-44.

5. Górska R, Pietruska M, Dembowska E, et al. Częstość występowania chorób przyzębia u osób w wieku 35-44 lat w populacji dużych aglomeracji miejskich. Dent Med Prob 2012; 49: 19-27.

6. Konopka T, Pietruska M, Dembowska E, et al. Oral and periodontal condition in 65-74 year-old Poles. J Stoma 2014; 67: 57-58.

7. Androsz O, Kwiatkowska-Jakubas W, Blachowicz A, et al. Ocena stopnia zaawansowania choroby przyzębia $u$ pacjentek z osteoporozą w zależności od stosowanej Hormonalnej Terapii Zastępczej i przyjmowanych leków. Doniesienie wstępne. Nowa Stom 2006; 2: 93-86.

8. Armitage GC. Development of a classification system for periodontal diseases and conditions. Ann Periodontol 1999; 4: 1-6.

9. Ainamo J, Barmes D, Beagrie G, et al. Development of the World Health Organization (WHO) community periodontal index of treatment needs (CPITN). Int Dent J 1982; 32: 281-291.

10. Page RC, Eke PI. Case definitions for use in population-based surveillance of periodontitis. J Periodontol 2007; 78 (Suppl. 7): 1387-1399.

11. Eke PI, Dye BA, Wei L, et al. Prevalence of periodontitis in adults in the United States: 2009 and 2010. J Dent Res 2012; 91: 914-920.
12. Baelum V, Lopez R. Defining a periodontitis case: analysis of a nevertreated adult population. J Clin Periodontol 2012; 39: 10-19.

13. Linden GJ, Lyons A, Scannapieco FA. Periodontal systemic associations: review of the evidence. J Periodontol 2013; 84 (Suppl. 4): S8-19.

14. Linden GJ, Herzberg MC. Periodontitis and systemic diseases: a record of discussions of working group 4 of the joint EFP/AAP Workshop on periodontitis and systemic diseases. J Periodontol 2013; 84 (Suppl. 4): S20-23.

15. Tonetti MS, Van Dyke TE. Periodontitis and atherosclerotic cardiovascular disease: consensus report of the Joint EFP/AAP Workshop on periodontitis and systemic diseases. J Periodontol 2013; 84 (Suppl. 4): S24-29.

16. Lockhart PB, Bolger AF, Papapapanou PN, et al. Periodontal disease and atherosclerotic vascular disease: does the evidence support an independent association? A scientific statement from the American Heart Association. Circulation 2012; 125: 2520-2544.

17. Wojtyniak B, Goryński P, Moskalewicz B. Sytuacja zdrowotna ludności Polski i jej uwarunkowania. Narodowy Instytut Zdrowia Publicznego Państwowy Zakład Higieny, Warszawa 2012.

18. Go AS, Mozaffarian D, Roger VL, et al. Executive summary: heart disease and stroke statistics - 2014 update. A report from the American Heart Association. Circulation 2014; 129: 399-410.

19. Dietrich T, Sharma P, Walter C, et al. The epidemiological evidence behind the association between periodontitis and incident atherosclerotic cardiovascular disease. J Periodontol 2013; 84 (Suppl. 4): S70-84.

20. Bochniak M, Sadlak-Nowicka J, Rynkiewicz A, Kusiek A. Relationship between periodontal status and the incidence of acute myocardial infarction. J Stoma 2011; 64: 579-597.

21. Włosowicz M, Wożakowska-Kapłon B, Górska R. Stan jamy ustnej u pacjentów z zawałem serca oraz ze stabilną dławicą piersiową. Now Stom 2012; 2: 75-79.

22. Wożakowska-Kapłon B, Włosowicz M, Gorczyca-Michta I, Górska R. Oral health status and the occurrence and clinical course of myocardial infarction in hospital phase: a case-control study. Cardiol J 2013; 20: 370-377.

23. Górski B, Włososwicz M, Dembowska E, et al. More than $40 \%$ of patients after cardiac infarct require immediate appliaction of specialist periodontal treatment. Mag Stom 2014; 1: 95-98 [in Polish].

24. Sosińska K. Occurence of periodontitis in patients after acute myocardial infarction. PhD Thesis, Pomorski Uniwersytet Medyczny w Szczecinie, 2014 [in Polish].

25. Sabbah W, Tsakos G, Chandola T, et al. The relationship between social network, social support and periodontal disease among older Americans. J Clin Periodontol 2011; 38: 547-552.

26. Kumar PS. Smoking and the subgingival ecosystem: a pathogen-enriched community. Futire Micribiol 2012; 7: 917-919.

27. Faveri M, Rebello A, Dias RO, et al. Clinical and micobiological effects of adjunctive metronidazole plus amoxicillin in the treatment of generalized chronic periodontitis: smokers versus non-smokers. J Periodontol 2014; 85: 581-591.

28. Bertoldi C, Lalla M, Pradelli JM, et al. Risk factors and socioeconomic condition effects on periodontal and dental health: a pilot study among adults over fifty years of age. Eur J Dent 2013; 7: 336-346. 